\title{
A web-based learning environment and its effectiveness on the level of teaching performance of Helwan, Sadat universities (Comparative study)
}

; Professor of curriculum, teaching methods at department of curriculum, teaching methods, training and sport kinesiology. faculty of P.E, University of Sadat City, Egypt.

; Assistant professor at department of curriculum, teaching methods, training and sport kinesiology. Faculty of P.E, University of Sadat City, Egypt.

; Assistant professor at department of Curriculum and Teaching Methods of Physical Education, Faculty of P.E, for girls at helwan University, Arab Republic of Egypt

\section{Introduction:}

\section{LEARNING ENVIRONMENT}

Learning environment refers to the diverse physical locations, contexts, and cultures in which students learn. Since students may learn in a wide variety of settings, such as outside-of-school locations and outdoor environments.[6][42]

The term also encompasses the culture of a school or class-its presiding ethos and characteristics, including how individuals interact with and treat one another-as well as the ways in which teachers may organize an educational setting to facilitate learninge.g., by conducting classes in relevant natural ecosystems, grouping desks in specific ways, decorating the walls with learning materials, or utilizing audio, visual, and digital technologies. And because the qualities and characteristics of a learning environment are determined by a wide variety of factors, school policies, governance structures, and other features may also be considered elements of a "learning environment." [6][43]

In The Glossary of Educational Reform, 29 August, 2014

This definition recognises that students learn in many different ways in very different contexts. Since learners must do the learning, the aim is to create a total environment for learning that optimises the ability of students to learn. There is of course no single optimum learning environment. There is an infinite number of possible learning environments, which is what makes teaching so interesting. [42][43]

Educators may also argue that learning environments have both a direct and indirect influence on student learning, including their engagement in what is being taught, their motivation to learn, and their sense of well-being, belonging, and personal safety. For example, learning environments filled with sunlight and stimulating educational 
materials would likely be considered more conducive to learning than drab spaces without windows or decoration, as would schools with fewer incidences of misbehavior, disorder, bullying, and illegal activity. How adults interact with students and how students interact with one another may also be considered aspects of a learning environment, and phrases such as "positive learning environment" or "negative learning environment" are commonly used in reference to the social and emotional dimensions of a school or class. [43]

\section{Components of an effective learning environment}

Developing a total learning environment for students in a particular course or program is probably the most creative part of teaching. While there is a tendency to focus on either physical institutional learning environments (such as classrooms, lecture theatres and labs), or on the technologies used to to create online personal learning environments (PLEs), learning environments are broader than just these physical components. They will also include:

- the characteristics of the learners;

- the goals for teaching and learning;

- the activities that will best support learning;

- $\quad$ the assessment strategies that will best measure and drive learning

- the culture that infuses the learning environment. [6][42]

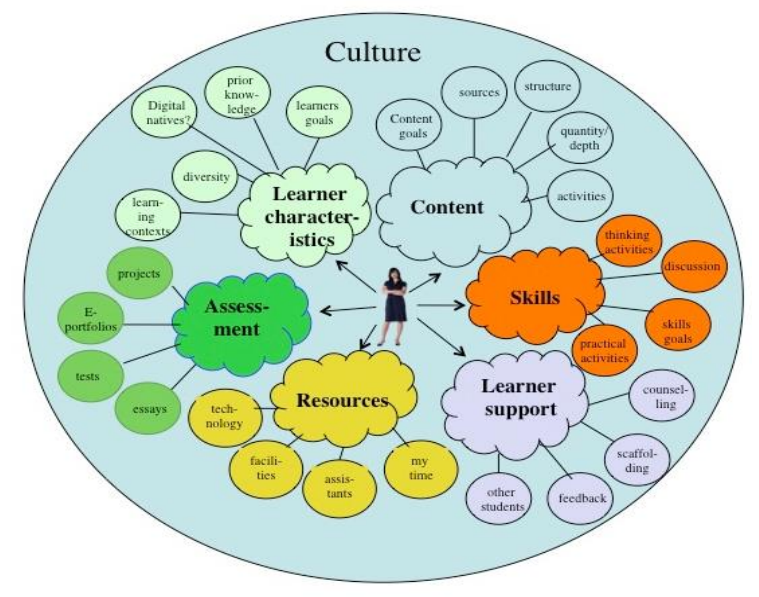

Figure 1, A learning environment from a teacher's perspective

Figure 1 illustrates one possible learning environment from the perspective of a teacher or instructor. A teacher may have little or no control over some components, such as learner characteristics or resources, but may have full control over other components 
such as choice of content and how learners will be supported. Within each of the main components there are a set of sub-components that will need to be considered. In fact, it is in the sub-components (content structure, practical activities, feedback, use of technology, assessment methods, and so on).[6][42]

I have listed just a few components in Figure 1 and the set is not meant to be comprehensive. For instance it could have included other components, such as developing ethical behaviour, institutional factors, or external accreditation, each of which might also affect the learning environment in which a teacher or instructor has to work. Creating a model of a learning environment then is a heuristic device that aims to provide a comprehensive view of the whole teaching context for a particular course or program, by a particular instructor or teacher with a particular view of learning. Once again, the choice of components and their perceived importance will be driven to some extent by personal epistemologies and beliefs about knowledge, learning and teaching methods. [6][42]

Lastly, I have deliberately suggested a learning environment from the perspective of a teacher, as the teacher has the main responsibility for creating an appropriate learning environment, but it is also important to consider learning environments from the learners' perspectives. Indeed, adult or mature learners are capable of creating their own, personal, relatively autonomous learning environments.[6][42]

The significant point is that it is important to identify those components that need to be considered in teaching a course or program, and in particular that there are other components besides content or curriculum. Each of the key components of the learning environment I have chosen as an example are discussed briefly in the following sections, with a focus on the components of a learning environment that are particularly relevant for a digital age. [6][42]

Although web design has a fairly recent history, it can be linked to other areas such as graphic design. However, web design can also be seen from a technological standpoint. It has become a large part of people's everyday lives. It is hard to imagine the Internet without animated graphics, different styles of typography, background, and music. [41]

Web design encompasses many different skills and disciplines in the production and maintenance of websites. The different areas of web design include web graphic design; interface design; authoring, including standardised code and proprietary 
software; user experience design; and search engine optimization. Often many individuals will work in teams covering different aspects of the design process, although some designers will cover them all.[17] The term web design is normally used to describe the design process relating to the front-end (client side) design of a website.[17][41]

\section{The start of the web and web design}

In 1989, whilst working at CERN Tim Berners-Lee proposed to create a global hypertext project, which later became known as the World Wide Web. During 1991 to 1993 the World Wide Web was born. Text-only pages could be viewed using a simple line-mode browser.[37] In 1993 Marc Andreessen and Eric Bina, created the Mosaic browser. At the time there were multiple browsers, however the majority of them were Unix-based and naturally text heavy. There had been no integrated approach to graphic design elements such as images or sounds. The Mosaic browser broke this mould.[12] The W3C was created in October 1994 to "lead the World Wide Web to its full potential by developing common protocols that promote its evolution and ensure its interoperability."[40] This discouraged any one company from monopolizing a propriety browser and programming language, which could have altered the effect of the World Wide Web as a whole. The W3C continues to set standards, which can today be seen with JavaScript. In 1994 Andreessen formed Communications Corp. that later became known as Netscape Communications, the Netscape 0.9 browser. Netscape created its own HTML tags without regard to the traditional standards process. For example, Netscape 1.1 included tags for changing background colours and formatting text with tables on web pages. Throughout 1996 to 1999 the browser wars began, as Microsoft and Netscape fought for ultimate browser dominance. During this time there were many new technologies in the field, notably Cascading Style Sheets, JavaScript, and Dynamic HTML. On the whole, the browser competition did lead to many positive creations and helped web design evolve at a rapid pace.[26][36][41]

Since the start of the 21st century the web has become more and more integrated into peoples lives. As this has happened the technology of the web has also moved on. There have also been significant changes in the way people use and access the web, and this has changed how sites are designed. [9][41] 


\section{User experience design and interactive design}

User understanding of the content of a website often depends on user understanding of how the website works. This is part of the user experience design. User experience is related to layout, clear instructions and labeling on a website. How well a user understands how they can interact on a site may also depend on the interactive design of the site. If a user perceives the usefulness of the website, they are more likely to continue using it. Users who are skilled and well versed with website use may find a more distinctive, yet less intuitive or less user-friendly website interface useful nonetheless. However, users with less experience are less likely to see the advantages or usefulness of a less intuitive website interface. This drives the trend for a more universal user experience and ease of access to accommodate as many users as possible regardless of user skill.[8] Much of the user experience design and interactive design are considered in the user interface design. [8][41]

\section{Homepage design}

Usability experts, including Jakob Nielsen and Kyle Soucy, have often emphasised homepage design for website success and asserted that the homepage is the most important page on a website.[14][27][28][34] However practitioners into the 2000s were starting to find that a growing number of website traffic was bypassing the homepage, going directly to internal content pages through search engines, e-newsletters and RSS feeds.[35][41]

According to the above, this study is based on designing a web-based learning environment, which offered content of lessons for the purpose of raising the level of teaching performance for P.E female students, The researchers observation during them work at the faculties of P.E that methods and means used teaching skills lacks the motivation of the learner and the desire to learn more skills.

Therefore, this study is an attempt to raise the performance of female students with one of the most modern methods in the field of teaching methods, by using learning environment via the web for studying its effect on teaching performance.

\section{Reseach objective:}


The aim of this study was designing a web-based learning environment and comparative its effects on the level of teaching performance (performance level of teaching skills) for practical education female students of Helwan, Sadat universities.

\section{Hypothesis:}

1- There are statistically significant differences between the average of the pre-and post-measurements for the two experimental groups (first, second) in the level of teaching performance (teaching skills) in favor to the post measurement for each group.

2- There are statistically significant differences in post measurements between the two experimental groups in the level of teaching performance (teaching skills) for practical education female students of Helwan, Sadat universities.

\section{Methodology}

\section{Method:}

The experimental approach was used for two experimental groups using pre- post measurements for each group.

\section{Research sample:}

The research community in the fourth class female students in faculty of P.E at Helwan and Sadat universities for the academic year 2018/2019. The basic sample was randomly selected from the female students of the research community. The total number of the sample was (60) female students from the research community at Helwan and Sadat Universities. The sample was divided into two experimental groups as follows:

- The first experimental group: The students of Helwan University, which uses the web-based learning environment, consists of (30) female students.

- Second experimental group: The students of Sadat University, which uses the webbased learning environment, consists of (30) female students.

And (14) female students of outside the basic research sample as exploration sample (7 students from Helwan university, 7 students from Sadat university). Thus, the basic sample and outside the basic research sample consisted of (74) female students.

\section{Tools:}


A. Data recording forms: Forms for recording the data for the research sample were prepared. (Appendix 1)

B. IQ test: Intelligence and mental abilities test was used, secondary and university stage verbal intelligence test, prepared by Gabir, Omar (2007) [11]. (Appendix 2)

Table (1)

Validity and stability of IQ test

$\mathrm{N}=10$ (test validity), $\mathrm{N}=14$ (test stability)

\begin{tabular}{|c|c|c|c|c|c|c|c|}
\hline \multirow[t]{2}{*}{ Variables } & \multirow[t]{2}{*}{ unit } & \multicolumn{2}{|c|}{$\begin{array}{c}\text { upper } \\
\mathrm{N}_{1}=\mathbf{5}(33 \%)\end{array}$} & \multicolumn{2}{|c|}{$\begin{array}{c}\text { lower } \\
\mathrm{N}_{2}=\mathbf{5}(33 \%)\end{array}$} & \multirow{2}{*}{$\begin{array}{c}\text { Mean } \\
\text { differences }\end{array}$} & \multirow{2}{*}{$\begin{array}{c}\text { T. } \\
\text { value }\end{array}$} \\
\hline & & M & $\pm \mathrm{SD}$ & M & $\pm \mathrm{SD}$ & & \\
\hline $\begin{array}{l}\text { Intelligence and } \\
\text { mental abilities }\end{array}$ & Degree & 90.76 & 1.93 & 86.41 & 1.69 & 4.35 & $3.39 *$ \\
\hline \multirow{2}{*}{ Variables } & \multirow{2}{*}{ unit } & \multicolumn{2}{|c|}{$\overline{\mathbf{1}_{\text {st }}}$} & \multicolumn{2}{|c|}{2} & \multirow{2}{*}{\multicolumn{2}{|c|}{$\mathrm{CC}$}} \\
\hline & & $\mathrm{M}$ & $\pm \mathrm{SD}$ & $\mathrm{M}$ & $\pm \mathrm{SD}$ & & \\
\hline $\begin{array}{l}\text { Intelligence and } \\
\text { mental abilities }\end{array}$ & Degree & 86.30 & 1.91 & 87.05 & 1.94 & \multicolumn{2}{|c|}{$0.943^{*}$} \\
\hline
\end{tabular}

The value of t-table at a significant level $(8,0.05)=2.30$ (two directions), the t-value (cc) at a significant level $(12,0.05)=0.591$ (two directions).

It is clear from Table (1) that there are statistically significant differences between the two upper, lower groups in favor of the upper group, indicating the validity of the test. It is also evident that there is a correlation between the first and second applications indicating the stability of the test.

C. Evaluation form of teaching skills: The form was used evaluation of teaching skills, prepared by Abdallah Abdel-Halim 2008 (Appendix 3). The form was purposed to identify the level of teaching skills performance for practical education students in physical education lesson. The form was prepared in 2008 through the following references: (Abdallah 2008), (Zeinab, Ghada 2008), (Essam 2008), (Moustafa, Fathy 2002), (Zaghloul, Hany 2001), (Zaghloul, Moustafa 2004), (Lamia 2002), (Ahmed et al. 2005), (Zaghloul et al. 2001), (Bodour, Suheir 2006), (Nisreen 2007), (Nawal, Mirvat 2002) and (Wafika 2002). [1][39][10][24][21][23][16][4][22][7][29][25][38]

The form contains (10) teaching skills, as shown in the following table: 
Table (2)

Teaching skills

\begin{tabular}{c|l}
\hline \hline No. & \multicolumn{1}{|c}{ Teaching skills } \\
\hline \hline 1 & Objectives determination \\
\hline 2 & Lesson planning \\
\hline 3 & Preparing lesson \\
\hline 4 & Presentation of the lesson \\
\hline 5 & Continuation of the lesson \\
\hline 6 & Diversity of stimuli and motivation for learning \\
\hline 7 & Teaching aids \\
\hline 8 & Classroom management \\
\hline 9 & Evaluation \\
\hline 10 & Teaching methods \\
\hline \hline
\end{tabular}

The form was presented to the experts at the faculties of physical education (appendix 5) for the purpose of identifying the experts' opinion. The percentage of the experts' agreement was calculated on phrases of the form. The agreement rates on the phrases ranged from $80 \%$ to $100 \%$.

\section{Scientific transactions of the form:}

Table (3)

Validity of Internal Consistency of the teaching skills form

$\mathrm{N}=14$

\begin{tabular}{c|c||c|c||c|c||c|c}
\hline \hline \multirow{2}{*}{$\begin{array}{c}\text { No. of } \\
\text { phrases }\end{array}$} & \multirow{2}{*}{$\begin{array}{c}\text { Correlation } \\
\text { coefficient }\end{array}$} & $\begin{array}{c}\text { No. of } \\
\text { phrases }\end{array}$ & $\begin{array}{c}\text { Correlation } \\
\text { coefficient }\end{array}$ & \multirow{2}{*}{$\begin{array}{c}\text { No. of } \\
\text { phrases }\end{array}$} & $\begin{array}{c}\text { Correlation } \\
\text { coefficient }\end{array}$ & $\begin{array}{c}\text { No. of } \\
\text { phrases }\end{array}$ & $\begin{array}{c}\text { Correlation } \\
\text { coefficient }\end{array}$ \\
\hline \hline 1 & 0.754 & 23 & 0.653 & 45 & 0.753 & 67 & 0.761 \\
\hline 2 & 0.782 & 24 & 0.842 & 46 & 0.892 & 68 & 0.656 \\
\hline 3 & 0.673 & 25 & 0.622 & 47 & 0.822 & 69 & 0.867 \\
\hline 4 & 0.789 & 26 & 0.904 & 48 & 0.784 & 70 & 0.855 \\
\hline 5 & 0.817 & 27 & 0.785 & 49 & 0.833 & 71 & 0.745 \\
\hline 5 & 0.68 & 28 & 0.863 & 50 & 0.842 & 72 & 0.749 \\
\hline 7 & 0.869 & 29 & 0.744 & 51 & 0.874 & 73 & 0.873 \\
\hline 8 & 0.889 & 30 & 0.745 & 52 & 0.779 & 74 & 0.841 \\
\hline 9 & 0.775 & 31 & 0.847 & 53 & 0.788 & 75 & 0.694 \\
\hline 10 & 0.922 & 32 & 0.874 & 54 & 0.707 & 76 & 0.846 \\
\hline 11 & 0.754 & 33 & 0.776 & 55 & 0.776 & 77 & 0.699 \\
\hline 12 & 0.824 & 34 & 0.713 & 56 & 0.723 & 78 & 0.758 \\
\hline 13 & 0.785 & 35 & 0.82 & 57 & 0.797 & 79 & 0.752 \\
\hline 14 & 0.797 & 36 & 0.715 & 58 & 0.744 & 80 & 0.847 \\
\hline 15 & 0.688 & 37 & 0.579 & 59 & 0.767 & 81 & 0.772 \\
\hline 16 & 0.866 & 38 & 0.796 & 60 & 0.788 & 82 & 0.739 \\
\hline 17 & 0.736 & 39 & 0.755 & 61 & 0.845 & 83 & 0.819 \\
\hline 18 & 0.752 & 40 & 0.746 & 62 & 0.863 & 84 & 0.852 \\
\hline
\end{tabular}




\begin{tabular}{c|c||c|c||c|c||c|c}
\hline \hline $\begin{array}{c}\text { No. of } \\
\text { phrases }\end{array}$ & $\begin{array}{c}\text { Correlation } \\
\text { coefficient }\end{array}$ & $\begin{array}{c}\text { No. of } \\
\text { phrases }\end{array}$ & $\begin{array}{c}\text { Correlation } \\
\text { coefficient }\end{array}$ & $\begin{array}{c}\text { No. of } \\
\text { phrases }\end{array}$ & $\begin{array}{c}\text { Correlation } \\
\text { coefficient }\end{array}$ & $\begin{array}{c}\text { No. of } \\
\text { phrases }\end{array}$ & $\begin{array}{c}\text { Correlation } \\
\text { coefficient }\end{array}$ \\
\hline \hline 19 & 0.869 & 41 & 0.865 & 63 & 0.854 & 85 & 0.849 \\
\hline 20 & 0.647 & 42 & 0.738 & 64 & 0.879 & 86 & 0.677 \\
\hline 21 & 0.755 & 43 & 0.797 & 65 & 0.938 & 87 & 0.878 \\
\hline 22 & 0.822 & 44 & 0.934 & 66 & 0.775 & 88 & 0.668 \\
\hline \hline
\end{tabular}

The t-value at a significant level $(12,0.05)=0.591$

It is clear from Table (3) that all the phrases has statistically significant greater than 0.591 and therefore was accepted all the terms and phrases of the form.

Table (4)

Stability of of the form

\begin{tabular}{|c|c|c|c|c|c|c|}
\hline \multirow{2}{*}{ Parameters } & \multicolumn{2}{|c|}{ First half } & \multicolumn{2}{|c|}{ Second half } & \multirow{2}{*}{$\begin{array}{c}\text { half }- \text { stability } \\
\text { Coefficient }\end{array}$} & \multirow{2}{*}{$\begin{array}{c}\text { Total stability } \\
\text { coefficient }\end{array}$} \\
\hline & $\mathrm{M}$ & $\pm \mathrm{SD}$ & $\mathrm{M}$ & $\pm \mathrm{SD}$ & & \\
\hline $\begin{array}{c}\text { Form of } \\
\text { teaching skills }\end{array}$ & 83.66 & 15.39 & 84.49 & 15.44 & 0.826 & 0.905 \\
\hline
\end{tabular}

The t-value at a significant level $(12,0.05)=0.591$

It is clear from Table (4) that there is a correlation between the first and second half, indicating the stability of the form.

Thus, the form was applied on the basic research sample (60 female students) before and after the implementation of the educational units on the two experimental groups.

\section{The web-based learning environment design:(Appendix 4)}

The web-based learning environment was designed as shown below:

1- Objective of learning environment: The learning environment was aimed to

Knowledge effect of using web on performance level of teaching skills for practical education female students in Cairo and Sadat.

2- Mental and skillful level of the research sample: The mental aspect of the study sample was determined by Intelligence and mental abilities test (Appendix 2). Also, the skillful aspect was determined by the evaluation form of teaching skills. (Appendix 3). 
3- Learning environment content: The learning environment content was determined of teaching skills through the following scientific references (Abdallah 2008), (Zeinab, Ghada 2008), (Essam 2008), (Moustafa, Fathy 2002), (Zaghloul, Hany 2001), (Zaghloul, Moustafa 2004), (Lamia 2002), (Ahmed et al. 2005), (Zaghloul et al. 2001), (Bodour, Suheir 2006), (Nisreen 2007), (Nawal, Mirvat 2002), (Wafika 2002), (Rehab 2016), (Abdallah 2018), (Zeinab O., Ghada G., 2008), (Mahmoud "good education" 2018), (Mahmoud "Structure and Policies" 2018) by including some multimedia; videos, pictures and texts. $[1][39][10][24][21][23][16][4][22][7][29][25][38][33][2][39][18][19]$

4- The web: The web site was designed contain the learning environment, "http://ahmedthussaam.wixsite.com/pecb-sports"(Appendix 4), The web consists of the following contents:

- The main page. Appendix4

- Contents of teaching skills:

a Skills of; Objectives determination, Lesson planning and Preparing lesson (including the preparation of physical education lesson, as well as the identification of the sections of the call, conditions and configurations of physical education lesson and how to prepare the tools, in addition to warm up and physical preparation and exercises).

- Skills of the main, final part of the lesson (including skills; presentation of the lesson, continuation of the lesson, diversity of stimuli and motivation for learning, classroom management, evaluation, teaching methods).

Some illustrations of the learning environment: Appendix4 
5- Style of teaching in learning environment: The teaching style was used in the learn environment was the individual learning method through the use of each individual student for the web.

\section{6- Learning environment features:}

- Repetition of images, graphics and video more than once.

- Sound control during video playback.

- Pause during video playback.

- Display and download text, images, graphics and video on full screen.

7- The experts' opinion: (appendix 5) The experts' opinion of learning environment (the main screen of the learning environment or the web, video, format, colors, images and texts) and agreement was obtained on the learning environment was designed, and the experts agreed to instructions and contents of the web (Appendix 4).

8- The exploratory study: The learning environment was tested by presenting the site on the sample of the exploratory study in order to identify the clarity of the pictures, drawings and video were learning environment contained on the web. The result of this experiment was the clarity of all the contents of the learning environment.

\section{Distribution of the learning environment content on the total units for two experimental groups:}

The time distribution of the teaching unites was standardized for the two experimental groups, The learning and implementation method for each group (The two experimental group) were via learning environment on the web. (Appendix 4) and as shown in the following table 
Table (5)

Distribution of the study content (learning environment content) on the total units of the two experimental research groups

\begin{tabular}{c|c|l}
\hline \hline No. of Unit & week & \multicolumn{1}{|c}{ Contents (teaching skills) } \\
\hline 1,2 & 1 & Objectives determination \\
\hline 3,4 & 2 & Lesson planning \\
\hline 5,6 & 3 & Preparing lesson \\
\hline 7,8 & 4 & Presentation of the lesson \\
\hline 9,10 & 5 & Continuation of the lesson \\
\hline 11,12 & 6 & Diversity of stimuli and motivation for learning \\
\hline 13,14 & 7 & Teaching aids \\
\hline 15,16 & 8 & Classroom management \\
\hline 17,18 & 9 & Evaluation \\
\hline 19,20 & 10 & Teaching methods \\
\hline \hline
\end{tabular}

\section{Application:}

The web-based learning environment was implemented on the basic study sample (60 female students), as shown in table (6):

Table (6)

Time distribution of the two experimental research groups

\begin{tabular}{l|l}
\hline \multicolumn{1}{c|}{ Contents } & \multicolumn{1}{c}{ Time } \\
\hline \hline Program Duration & 10 weeks \\
\hline Number of units (lessons) per week & 2 units in week \\
\hline Unit Number & 20 units \\
\hline Unit time & $45 \mathrm{~m}$ \\
\hline \hline
\end{tabular}

\section{learning environment was implemented as follow:}

- First, the female students seing the explanation, information, knowledge and learning environment videos of the teaching skills on the website before implementation in the school of practical education.

- Students know through the learning environment or through the researchers what is required preparation of the duties and tasks for the part to be implemented in the school of practical education. 
- The implementation of the students for what was seen in the court in practical education school.

- The researchers observing the students' performance during the implementation of what was seen. The researchers correct for errors and provide feedback and adjust the performance of students.

\section{Moderation of sample distribution:}

Table (7)

Distribution moderation for basic and exploratory research sample

$\mathrm{N}=74$

\begin{tabular}{|c|c|c|c|c|c|}
\hline \multirow{2}{*}{ Parameters } & \multirow{2}{*}{ Unit } & \multicolumn{4}{|c|}{ Statistical analyses } \\
\hline & & Mean & Median & \pm SD & SK \\
\hline Age & year & 21.25 & 1.10 & 21.00 & 0.68 \\
\hline Intelligence & degree & 86.50 & 1.88 & 87.00 & -0.80 \\
\hline $\begin{array}{l}\text { Evaluation form of } \\
\text { teaching skills }\end{array}$ & degree & 166.80 & 18.69 & 167.00 & -0.03 \\
\hline
\end{tabular}

Table (7) shows that the values of Skewness coefficients ranged from \pm (3), indicating the moderated distribution of the basic and exploratory sample.

Sample equivalence (Pre- measurement):

Table (8)

Equivalence of the two research groups (tribal measurements)

$\mathrm{N}=60$

\begin{tabular}{l||c|c|c|c||c|c}
\hline \hline \multirow{2}{*}{\multicolumn{1}{c||}{ Parameters }} & \multicolumn{2}{c|}{$\begin{array}{c}\text { First } \\
\text { experimental } \\
\text { N=30 }\end{array}$} & \multicolumn{2}{c||}{$\begin{array}{c}\text { Second } \\
\text { experimental } \\
\text { N=30 }\end{array}$} & $\begin{array}{c}\text { Mean } \\
\text { Differences }\end{array}$ & \multirow{2}{*}{$\mathbf{T}$} \\
\cline { 2 - 6 } & $\mathrm{M}$ & $\mathrm{SD} \pm$ & $\mathrm{M}$ & $\mathrm{SD} \pm$ & & \\
\hline \hline Age & 21.14 & 1.06 & 21.18 & 1.10 & 0.04 & 0.76 \\
\hline Intelligence form & 86.52 & 1.91 & 86.58 & 1.92 & 0.06 & 0.84 \\
\hline $\begin{array}{l}\text { Evaluation } \\
\text { teaching skills }\end{array}$ & 169.00 & 20.51 & 169.05 & 20.54 & 0.05 & 0.80 \\
\hline \hline
\end{tabular}

$\mathrm{T}$ Table value at a significant level $(58,0.05)=2.00$ (two directions)

Table (8) shows that all the values of the previous variables are not statistically significant, indicating that there are no statistically significant differences and thus the equivalence of the two experimental research groups. 


\section{Results}

Table (9)

Significance of the mean differences between the pre- post and post-post measurements of the two experimental groups teaching skills

\begin{tabular}{|c|c|c|c|c|c|c|}
\hline \multirow{3}{*}{ Parameters } & \multicolumn{3}{|c|}{$\begin{array}{l}\text { First experimental } \\
\text { (Cairo students) }\end{array}$} & $T_{1}=30$ & \multirow{3}{*}{$\begin{array}{c}\text { Mean } \\
\text { Differences }\end{array}$} & \multirow{3}{*}{ T value } \\
\hline & \multicolumn{2}{|c|}{ Pre } & \multicolumn{2}{|c|}{ Post } & & \\
\hline & M & $\mathrm{SD} \pm$ & M & $\mathrm{SD} \pm$ & & \\
\hline $\begin{array}{l}\text { Evaluation form of } \\
\text { teaching skills }\end{array}$ & 169.00 & 20.51 & 185.92 & 12.58 & 16.92 & $17.51^{*}$ \\
\hline \multirow{4}{*}{ Parameters } & \multirow{2}{*}{\multicolumn{4}{|c|}{ 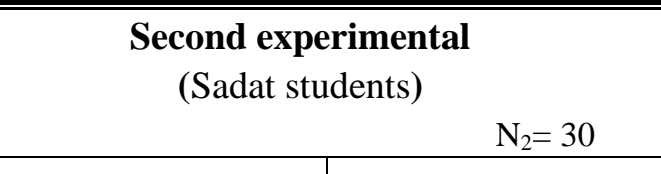 }} & \multirow{4}{*}{$\begin{array}{c}\text { Mean } \\
\text { Differences }\end{array}$} & \multirow{4}{*}{ T value } \\
\hline & & & & & & \\
\hline & \multicolumn{2}{|c|}{ Pre } & \multicolumn{2}{|c|}{ Post } & & \\
\hline & M & $\mathrm{SD} \pm$ & M & $\mathrm{SD} \pm$ & & \\
\hline $\begin{array}{l}\text { Evaluation form of } \\
\text { teaching skills }\end{array}$ & 169.05 & 20.54 & 186.96 & 12.60 & 17.91 & $18.30^{*}$ \\
\hline \multirow{4}{*}{ Parameters } & \multirow{2}{*}{\multicolumn{4}{|c|}{ Post }} & \multirow{4}{*}{$\begin{array}{c}\text { Mean } \\
\text { Differences }\end{array}$} & \multirow{4}{*}{ T value } \\
\hline & & & & & & \\
\hline & \multicolumn{2}{|c|}{ First experimental } & \multicolumn{2}{|c|}{$\begin{array}{c}\text { Second } \\
\text { experimental }\end{array}$} & & \\
\hline & M & $\mathrm{SD} \pm$ & M & $\mathrm{SD} \pm$ & & \\
\hline $\begin{array}{l}\text { Evaluation form of } \\
\text { teaching skills }\end{array}$ & 185.92 & 12.58 & 186.96 & 12.60 & 1.04 & 1.87 \\
\hline
\end{tabular}

Table (9) shows statistically significant differences between Pre-Post measurements of the two experimental groups at a significant level of 0.05 , and no differences (No significant differences) in post measurements between the two experimental groups at a significant level of 0.05 . 


\section{Discussion}

\section{First research hypotheses:}

The results of Table (9) show that there are statistically significant differences between pre and post mean values of the two experimental groups (first, second) in the level of teaching performance (performance level of teaching skills) in favor to the post measurement.

These results indicate that the learning environment based on the web was a positive effect on the skillful level under research (teaching skills). This indicates that the learning environment led to the correct perception of how to perform teaching skills in P.E lesson. The images, drawings, texts and videos were attached to the learning environment was a positive result on the skillful performance level, which is how to emplement the teaching skills in schools of practical education in P.E lesson.

The previous results is consistent with many studies which was indicated that use of the Internet in the educational process shows an improvement and effectiveness in the learning process in general, such as the study of (Ahmed 2011)[5], (Rania 2008)[30], (Rasha 2007)[31], (Mar Pérez et al. 2015)[20], (Koen et al. 2015)[15], (Abdallah 2018)[2], (Rehab 2011)[32], (Rehab 2016)[33], (Jean, Charles 2015)[13].

Thus, the researchers attributed the reason of differences between pre and post measurements to the experimental variable only, which is the learning environment based on the web. The researchers also attributes the progress in skillful performance (teaching skills) to relying on the learning environment and its various media (texts, pictures, graphics, audio and video) and thus a positive effect on variables of research (teaching skills of P.E) and this is due to the attractiveness and effectiveness of learning environment via the web.

Thus, the first hypothesis is achieved, which stated that there are statistically significant differences between the pre-and post-measurements for the two experimental groups (first, second) in the level of teaching performance (teaching skills) in favor to the post measurement for each group.

Second research hypotheses: 
The results of Table (9) show that there are no statistically significant differences in post mean values between the two experimental groups (first, second) in the level of teaching performance (performance level of teaching skills), where the value of calculated $(\mathrm{t})(1.87)$ is less than the value of table $(\mathrm{t})$ at a significant level $(0.05)$, which indicates the higher level of learn for the experimental group (learning environment) than the controlled group (explanation and presentation).

These results indicate that the learning environment based on the web was understood for the two experimental groups (first, second) and neither had a preference over the other in the performance level of teaching skills under research.

The researchers attributes this to that the IT revolution (Information Technology revolution) in the current era led to students' understanding of technology and its use through the web under the e-learning system and e-learning environments

It also shows that the tremendous or great technological progress and the development of technology and informatics reflected on the ability of female students to use the devices and the modern communication mechanisms of computers, mobile devices and Internet networks, Thus the positive effect of both experimental groups in the same amount or the same effect which led to the absence of differences between the two experimental groups in superiority of either of them over the other when using the webbased learning environment (learning environment via the web).

The above is consistent with the study both of Jean, Charles (2015), which indicated that the using of technology in the educational process has effective in learning in general. [13]

Thus, the second hypothesis, which stated that there are statistically significant differences in post measurements between the two experimental groups in the level of teaching performance (performance level of teaching skills) for practical education female students of Helwan, Sadat universities, is denied 
Therefore, the second hypothesis is no achieved, because the web-based learning environment (learning environment via the web) has a positive effect of two experimental groups (first, second) in the same amount or the same effect which led to the absence of differences between the two experimental groups in superiority of either of them over the other.

\section{Conclusions}

- Learning environment using the web has effective on the level of teaching performance (performance level of teaching skills) for the two experimental groups (first, second).

- The absence of differences between the two experimental groups in superiority of either of them over the other when using Learning environment based on the web.

\section{Recommendations}

- Encouraging the using learning environment based on the web because of its positive effect in the level of teaching performance (performance level of teaching skills under research).

- Introducing learning through the web within the curricula of the scientific subjects in the faculties of physical education.

- Conducting further studies on the effectiveness of learning environment through the web in cognitive, emotional and skillful aspects. 


\section{References}

1. Abdallah A. Mohamed: Effect of Self Learning Program on Performance of the Educational Skills for Student Teacher in the Practical Education, PhD Thesis, Faculty of Physical Education, Sadat University, 2008.

2. Abdallah A. Mohamed: Effectiveness of distance education using mobile applications on performance level some sports activities in P.E. lesson, The Assiut Journal of Sports Science and Arts (AJSSA), Website: www.AJSSA.net, Print; ISNN: 23147091, Online; ISNN: 2314-7105, Faculty of Physical Education, Assiut university, Volume: (A), Page number 39-61, January 4, 2018.

3. Abdallah Abdel-Halim Mohamed, Rehab Adel Gabal: Teaching in the light of the contemporary reality of sports education (concepts - principles - applications), World Sports Foundation for publishing and Dar Al-Wafaa for printing, $3^{\text {rd }}$, p.340, Alexandria 2018.

4. Ahmed Abdel-Aziz Maarek, Jehan Hamid Ismail, Hala Ahmed El-Kady: "Proposed program for the development of teaching performance of physical education teachers and its impact on the cognitive competence of teaching"published research, Journal of Physical Education Faculty, Tanta University 2005.

5. Ahmed Saher Hassanein. The Impact of Using the International Information Network on Learning Some Basic Skills in Football for Students of the Second Division, Faculty of Physical Education, Menofya University. World Journal of Sport Sciences “WJSS”, Vol.4 Numb. 3 , ISSN 2078-4724, pp:277-291. June 2011.

6. Anthony William (Tony), What is a learning environment? Bates is licensed under a Creative Commons Attribution-NonCommercial 4.0 International License, at https://opentextbc.ca/teachinginadigitalage/chapter/5-2-what-is-a-learningenvironment/, March 202018.

7. Bodour Al-Mutawa, Suheir Badir: Physical Education "Curricula and Methods of Teaching" Book Center, 2nd Edition, Cairo 2006.

8. Castañeda, J.A Francisco; Muñoz-Leiva, Teodoro Luque (2007). "Web Acceptance Model (WAM): Moderating effects of user experience". Information \& Management. 44: 384-396.doi:10.1016/j.im.2007.02.003.

9. Christensen, Mathias Biilmann (2015-11-16). "Static Website Generators Reviewed: Jekyll, Middleman, Roots, Hugo". Smashing Magazine. Retrieved 2016-10-26.

10. Essam El-Din Metwally Abdallah: Methods of teaching physical education between theory and practice, the world of sports publishing and Dar Al-Wafa for printing, Alexandria 2008. 
11. Gabir Abdel-hamid Gabir, Mahmoud Ahmed Omar: Linguistic intelligence Test of secondary and university stage, Dar al-Nahda Arab, p.1-13, Cairo 2007.

12. James Hendler. History of the Internet Tutorial, "Mosaic Browser" (PDF). Retrieved 2012-03-16 at http://www.techopedia.com/images/pdfs/history-ofthe-internet.pdf, available on Internet: https://www.techopedia.com/6/27861/internet/history-of-the-internet. January, 2019.

13. Jean Chastre, Charles-Edouard: Factors affecting the e-learning outcomes, Telematics and Informatics, Volume 32, Issue 4, November 2015, Pages 701-719.

14. Knight, Kayla (20 August 2009), Essential Tips for Designing an Effective Homepage, Six Revisions, archived from the original on 21 August 2013

15. Koen Aesaert, Daniël Van Nijlen, Ruben Vanderlinde, Jo Tondeur, Ines Devlieger, Johan van Braak, The contribution of pupil, classroom and school level characteristics to primary school pupils' ICT competences: A performancebased approach, Computers \& Education, Volume 87, September 2015, Pages 55-69.

16. Lamia Mohamed Ibrahim: "Effectiveness of using the educational bag on the performance efficiency of the teacher in physical education lesson", unpublished PhD Thesis, Faculty of Physical Education Gezera, Helwan University 2002.

17. Lester, Georgina. "Different jobs and responsibilities of various people involved in creating a website". Arts Wales UK. Retrieved2012-03-17.

18. Mahmoud Abdel-Halim Abdel-karim: school sports system - good education, teaching skills, teacher and efficiency standards, Arab Thought House (Dar El Fikr El Araby), Cairo 2018a.

19. Mahmoud Abdel-Halim Abdel-karim: school sports system - Structure and Policies, Curriculum and Curriculum, Calendar, Arab Thought House (Dar El Fikr El Araby), Cairo $2018 b$.

20. Mar Pérez-Sanagustín, Pedro J. Muñoz-Merino, Carlos Alario-Hoyos, Xavier Soldani, Carlos Delgado Kloos. Lessons learned from the design of situated learning environments to support collaborative knowledge construction, Computers \& Education, Volume 87, September 2015, Pages 70-82, 2015. 
21. Mohamed Saad Zaghloul, Hany Said Abdel-Moneim: "The Effect of a Proposed Program for Educational Performance Capacities on the Improvement of Some Competencies during the Period of Practical Education of the Teaching Student in the Teaching Division", Journal of Comprehensive Education Research, Volume 1, Second Half, Faculty of Physical Education for Girls, Zagazig University 2001.

22. Mohamed Saad Zaghloul, Makarem Helmi Abu Harja, Radwan Mohamed Radwan: Encyclopedia of Field Training in Physical Education, Book Center, Cairo 2001.

23. Mohamed Saad Zaghloul, Moustafa El-Sayeh Mohamed: The preparation and rehabilitation of the teacher of physical education, Dar Al-Wafa, 2nd Edition, Alexandria 2004.

24. Moustafa El-Sayeh Mohamed, Fathy El-Kordany: Practical Education between Theory and Practice, University House, Alexandria, 2002.

25. Nawal Ibrahim Shaltout, Mirvat Ali Khafaja: Teaching methods in physical education "Teaching and Learning" Part II, Al-Eshaa library, Alexandria 2002.

26. Niederst, Jennifer. Web Design In a Nutshell. United States of America: O'Reilly Media. pp. 12-14. ISBN 0-596-00987-9, 2006.

27. Nielsen, Jakob (10 November 2003), The Ten Most Violated Homepage Design Guidelines, Nielsen Norman Group, archived fromthe original on 5 October 2013.

28. Nielsen, Jakob; Tahir, Marie (October 2001), Homepage Usability: 50 Websites Deconstructed, New Riders Publishing, ISBN 978-0735711020

29. Nisreen Mohamed Al-Sharkawi: "The Systemic Approach Using the Computer and its Effect on Learning Teaching Skills for Female Students of Physical Education Faculty, Menoufia University" Unpublished PhD Thesis, Faculty of Physical Education, Sadat University, 2007.

30. Rania Mohamed Hassan: "Designing an educational site for field and track competitions using the internet" Third International Scientific Conferenc, Faculty of Physical Educatio, Alexandria University 2008.

31. Rasha Najih Aly: "A proposed educational program through the design of a web site model and its impact on learning some skills of rhythmic exercises for for the physical education faculty students, Minia University" unpublished PhD thesi, Faculty of Physical Education, Minia University 2007. 
32. Rehab Adel Gabal: "Designing an educational program using the international information network and its impact on the implementation on the physical education lesson aspects in the light of the overall quality standards", Journal of Science and Sports Arts - Volume 39 - Faculty of Physical Education, Gezera, Helwan University, June 2011.

33. Rehab Adel Gabal: Effectiveness of e-study on learning physical exercises and teaching formations, The Assiut Journal of Sports Science and Arts (AJSSA), Website: www.AJSSA.net, Print; ISNN: 2314-7091, Online; ISNN: 2314-7105, Faculty of Physical Education, Assiut university, Volume: (C), Page number 130-145, December 28, 2016.

34. Soucy, Kyle, Is Your Homepage Doing What It Should?, Usable Interface, archived from the original on 8 June 2012

35. Spool, Jared (29 September 2005), Is Home Page Design Relevant Anymore?, User Interface Engineering, archived from the originalon 16 September 2013

36. Tim-Berners Lee. Longer Biography, at https://www.w3.org/People/BernersLee/Longer.html, 9 January, 2019.

37. Tim-Berners Lee, Wendy Hall, James A. Hendler, Kieron O'Hara, Nigel Shadbolt and Daniel J. Weitzner, A Framework for Web Science, Foundations and Trends in Web Science, Volume 1, Issue 1 (also available as a book: ISBN: 1-933019-336 144pp September 2006)

38. Wafika Mustafa Salem: Teaching and Learning Technology in Physical Education, Knowledge Establishment press, Part 1, Alexandria 2002.

39. Zeinab Ali Omar, Ghada Galal Abdulhakim: Teaching methods of physical education "theoretical foundations and practical applications" Arab Thought House (Arab Dar Al-fekr), Cairo 2008.

40. Zwicky, E.D, Cooper, S and Chapman, D.B. Building Internet Firewalls. United States: O'Reily \& Associates. p. 804. ISBN 1-56592-871-7.CS1 maint: Uses authors parameter (link), 2010.

41. https://en.wikipedia.org/wiki/Web_design

42. https://opentextbc.ca/teachinginadigitalage/chapter/5-2-what-is-a-learningenvironment/

43. https://www.edglossary.org/learning-environment/ 